\title{
ASPEK-ASPEK PENTING UNTUK DIPAHAMI OLEH \\ PARA AHLI/PRAKTISI HUKUM TERHADAP PENYUSUNAN \\ LAPORAN KEUANGAN \\ PADA SUATU PERSEROAN TERBATAS \\ (SUATU PENDEKATAN GOOD CORPORATE GOVERNANCE)
}

\author{
Ari Wahyudi Hertanto ${ }^{1}$
}

\begin{abstract}
Abstrak
The company financial report in Indonesia does comply to Company Law that recent is Law number 40 year 2007 that applied to either private or public company as had governed at article 56 previous company law. Role and function of lawyer in this subject is to assure that the financial structure reported has reliability and accountability under legal concerns. This article is focused not only on company law aspect but also submits deeper thoughts by more relevant factors. It's embarked on knowledge of standard profession that giving supports behind the financial report creation. Many affiliated professions those also have different concern but here they are ought to perform mutualism symbiosis under thought that they are have dependency and relevancy each other.
\end{abstract}

Kata kunci: hukum dagang, perseroan terbatas, laporan keuangan

\section{Pendahuluan}

Satu dogma yang klasik, khususnya bagi siapapun yang memilih hukum sebagai pendidikan lanjutan selepas SMU, yaitu salah satunya adalah dikarenakan banyak diantara mereka bermaksud untuk menghindar dari berbagai hal yang terkait dengan berbagai macam bentuk perhitungan matematis. Pelak tak dapat dihindari pada akhirnya setelah berkecimpung dalam dunia hukum tidak dapat beralih dari kenyataan, bahwa pada muaranya seorang yuris pada akhirnya tetap harus bersinggungan dengan bidang yang satu ini. Perseroan terbatas merupakan salah satu wadah dari

${ }^{1}$ Penulis adalah pengajar Mata Kuliah Ilmu Negara dan Mata Kuliah Pancasila pada Fakultas Hukum Universitas Indonesia dan pengajar Mata Kuliah-Mata Kuliah Ilmu Negara, Hukum Perusahaan, Pendidikan Pancasila dan Kewarganegaraan dan Hukum Perdata pada Fakultas Hukum Universitas Al Azhar Indonesia. 
berbagai macam transaksi komersial, dimana hukum dalam hal ini memberikan reservasi terhadap bagaimana mekanisme kinerja dari sebuah badan hukum yang berbentuk perseroan terbatas dimaksud. Keterkaitan antara aspek komersil dan hukum pada sebuah perseroan terbatas sudah merupakan ikatan yang tidak terpisahkan. Setiap transaksi komersil senantiasa memerlukan landasan yuridis yang dipergunakan sebagai bentuk kepastian hukum dalam berbisnis, termasuk dan tidak terbatas bagi para pengusaha yang berupaya untuk melakukan bentuk-bentuk penyimpangan transaksi, tidak jarang berupaya semaksimal mungkin untuk juga bersembunyi dibalik perlindungan yuridis. Setidaknya, transaksi tersebut terkesan jauh dari unsur ilegalitas.

Laporan tahunan (annual report) adalah laporan yang dibuat oleh direksi untuk dan diajukan kepada Rapat Umum Pemegang Saham (RUPS). Laporan tahunan dalam aktualisasinya merupakan pelaksanaan prinsip keterbukaan dan pengungkapan yang berfungsi memberikan gambaran yang jelas positif, dan benar mengenai perusahaan. ${ }^{2}$ Melalui laporan tahunan tersebut secara implisit memuat keseluruhan prinsip-prinsip maupun doktrindoktrin modern yang berkembang dalam lingkup hukum perusahaan. Sehingga tidak salah apabila dikatakan bahwa laporan tahunan juga merupakan etalase, dimana pihak manapun dapat melihat kondisi dari suatu perusahaan.

Laporan tahunan merupakan salah satu wujud implementasi prinsip good corporate governance, yakni transparansi dan pengungkapan informasi tentang kinerja perusahaan, dimana kaitan keduanya adalah dengan penjelasan adanya rincian dalam laporan tahunan tersebut merupakan indikasi penerapan prinsip-prinsip corporate governance. Sekilas pandang tentang pentingnya laporan tahunan dari beberapa kalangan yang dikaitkan dengan prinsip good corporate governance, yaitu: ${ }^{3}$

The corporate governance framework should ensure that timely and accurate disclosure is made on all material regarding the corporation, including the financial situation, performance, ownership and the governance of the company.

${ }^{2}$ Ki Agus Umar Tochfa, Direktur Keuangan PT. ANTAM Tbk., Membuat Annual Report yang Efektif serta Sesuai dengan Prinsip-Prinsip Good Corporate Governance dan Studi Kasus, disampaikan dalam Seminar Good Annual Report dalam Perspektif Good Corporate Governance di Hotel Mulia, 28 Oktober 2002, hal. 2.

${ }^{3}$ Ibid., hal. 3 . 


\section{- Organization of Economic Cooperation and Development (OECD)}

Perseroan wajib mengungkapkan informasi penting dalam laporan tahunan dan laporan keuangan perseroan kepada pemegang saham, dan instansi pemerintah yang terkait sesuai dengan peraturan perundangundangan yang berlaku secara tepat waktu, akurat jelas dan obyetif.

OECD melalui Prinsip-Prinsip Good Corporate Governance 2004 mengumumkan beberapa prinsip tentang good corporate governance yang dalam hal ini terdiri dari 6 (enam) hal yang meliputi: (i) memastikan basis pelaksanaan kerangka kerja corporate governance secara efektif (ensuring the basis for an effective corporate governance framework); (ii) hak para pemegang saham dan fungsi kunci atas kepemilikan (the rights of shareholders and key ownership functions); (iii) perlakuan sewajarnya para pemegang saham (the equitable treatment of shareholders); (iv) peran para pemegang saham dalam corporate governance (the role of shareholders in corporate governance); (v) keterbukaan dan transparansi (disclosure and transparency); dan (vi) tanggung jawab dewan (the responsibilities of the board). Pada prinsipnya dapat dirangkum menjadi sebagai berikut:

1. Perlakuan yang setara atau wajar (equitable treatment or fairness);

2. Transparansi (transparency);

3. Akuntabilitas (accountability); dan

4. Tanggung jawab (responsibility).

\section{- $\quad$ IICGI}

Badan Usaha Milik Negara wajib mengungkapkan informasi penting dalam laporan tahunan dan laporan keuangan Badan Usaha Milik Negara kepada pemegang saham/pemilik modal, instansi pemerintah yang terkait sesuai dengan peraturan perundang-undangan yang berlaku secara tepat waktu, akurat, jelas dan secara obyektif.

- Kementerian Negara Badan Usaha Milik Negara, 1 Agustus 2002

Hal menarik lainnya dalam menilik istilah corporate governance sebenarnya bukan merupakan sesuatu hal yang baru dikarenakan telah seringkali diperdengarkan, akan tetapi pada kenyataannya pemberian definisi atas konsep tersebut sampai saat ini dipandang masih belum memadai. Semisal pemahaman yang paling sederhana yang dapat diberikan adalah, good corporate governance secara struktur adalah sama seperti neraca keuangan dalam konsep permodalan yang disajikan secara efektif dan rinci 
sebagai bentuk hak dan tanggung jawab dari masing-masing stakeholder (pemangku kepentingan) dalam suatu perusahaan. ${ }^{4}$

Masih segar dalam ingatan kita tentang peristiwa runtuhnya Enron Corporation, dimana masyarakat Amerika Serikat pada saat terjadinya peristiwa tersebut akan selalu menyempatkan diri untuk membaca artikel tentang skandal korporasi yang terbesar sepanjang sejarah Amerika Serikat. Media televisi maupun media cetak lainnya melaporkan secara berkesinambungan tentang bagaimana perusahaan-perusahaan bonafid seperti Enron, WorldCom, Global Crossing dan Qwest telah menyesatkan publik tentang laporan pertumbuhan keuangan dan pendapatannya, yang dipergunakan untuk menaikkan nilai saham dan mempertahankan rating perusahaan yang diberikan oleh para analisis. Sementara itu direksi dan pihak manajemen masing-masing perusahaan diinvestigasi atas tindakannya yang telah melakukan manipulasi terhadap laporan keuangan perusahaan untuk menutup informasi tentang kerugian yang luar biasa pada perusahaannya termasuk hutang-hutangnya. Dengan terbongkarnya peristiwa tersebut, maka kepercayaan investor dan harga saham dipasaran Amerika Serikat anjlok, dan berdampak pada kerugian yang mencapai milyaran dollar.

Salah satu dari sekian banyak investornya yang telah sangat dirugikan adalah para pegawai perusahaan. Animo untuk menanamkan dana pensiun yang dimilikinya melalui kepemilikan saham dalam perusahaan sangatlah tinggi, terutama apabila pasar dan harga saham melonjak. Pegawai tersebut tidak hanya kehilangan pekerjaan tetapi juga kehilangan seluruh tabungan dana pensiunnya. Amerika Serikat dalam menyikapi keadaan ini melalui houses of Congress secara cepat yaitu dengan mengajukan proposal untuk dilakukannya perubahan terhadap Employee Retirement Income Security Act of 1974 (ERISA) tentang investasi dalam saham perusahaan dan salah seorang senator yaitu Senator Daschle telah menyampaikan rencananya untuk memberikan suatu undang-undang yang menjanjikan bahwa terhadap peserta program investasi tersebut dapat mengajukan tuntutan terhadap pihak eksekutif perusahaan yang telah memberikan informasi palsu tentang perusahaan maupun sahamnya. ${ }^{5}$

Upaya konkrit pemerintah Amerika Serikat dilakukan dengan menerbitkan the Sarbanes - Oxley Act of 2002 (SOA) yang diterbitkan pada

${ }^{4}$ Low Chee Keong, Introduction the Corporate Governance Debate, Corporate Governance an Asia Pacific Critique, Sweet \& Maxwell Asia a Thompson Company, p. 3.

5 David M. Gische \& Jo Ann Abramson of Ross Dixon \& Bell, LLP, $<$ http://www.findlaw.com/Corporate_Fiduciary_Liability_Claims_in_the_Post-Enron_Era $>$, $<\mathrm{http} / / /$ articles.corporate.finlaw.com/articles/file/00295/00 8474 . 
tanggal 23 Juli 2002. SOA secara signifikan diharapkan dapat merubah perilaku profesi akuntansi di dunia. Selanjutnya diterbitkan Corporate and Criminal Fraud Accountability Act of 2002, yang melarang pemusnahan atau penciptaan dokumen untuk menghambat atau mempengaruhi investigasi. Kepada karyawan emiten dan kantor akuntan diberikan perlindungan whistle blower protector untuk mengungkapkan informasi yang menyangkut gugatan fraud. ${ }^{6}$

Pada saat kita berbicara tentang laporan tahunan, maka sudah barang tentu didalamnya terdapat muatan laporan keuangan. Contoh menarik lainnya yang dapat dikemukakan adalah terhadap laporan keuangan Kimia Farma yang overstated. Seperti diketahui beberapa waktu lalu terungkap kasus dugaan mark up laporan keuangan PT. Kimia Farma. Penggelembungan dana bersih pada laporan keuangan PT. Kimia Farma (senilai Rp.32,668 miliar, karena laporan keuangan yang seharusnya Rp.99,594 miliar ditulis Rp.132 miliar) ini didesak untuk dibawa kepengadilan. Kasus ini turut menyeret sebuah Kantor Akuntan Publik (KAP) yang menjadi auditor PT Kimia Farma, sekalipun KAP tersebut yang berinisiatif memberikan laporan adanya overstated tersebut. Dalam kasus ini terjadi pelanggaran terhadap prinsip pengungkapan yang akurat (accurate disclosure) dan transparansi (transparency) yang jelas sangat merugikan para investor, karena keuntungan yang overstated ini tentu telah dijadikan dasar transaksi oleh para investor (namun ketika terjadi kesalahan diumumkan, harga saham akan turun, dan investor dirugikan). ${ }^{\text {? }}$

Ilustrasi tersebut di atas merupakan salah satu dari sekian banyak contoh yang terjadi dalam skala internasional maupun nasional berkenaan dengan dampak penting yang ditimbulkan oleh laporan tahunan. Tidak lain dikarenakan didalamnya terdapat kepentingan para stakeholder (pemangku kepentingan) suatu perusahaan, dimana para stakeholder (pemangku kepentingan) ini pada hakekatnya mewakili berbagai macam individu yang turut terpengaruh oleh kegiatan perusahaan, termasuk didalamnya antara lain aspek-aspek manajemen, pemegang saham, kreditur, karyawan, konsumen dan masyarakat pada umumnya.

${ }^{6}$ Ludovicus Sensi W., Tanggung Jawab Akuntan Manajemen dan Akuntan Publik atas Skandal Akuntansi (Korporasi) dilihat dari sudut pandang Akuntan Publik (Global Issues and Perspective), disampaikan pada Akuntansi untuk Praktisi Hukum, yang diselenggarakan oleh LPLIH-FHUI, Mei 2003, hal. 14.

${ }^{7}$ I. Nyoman Tjager, F. Antonius Alijoyo, Humphrey R. Djemat, dan Bambang Soembodo, "Corporate Governance - Tantangan dan Kesempatan bagi Komunitas Bisnis Indonesia", (Jakarta: PT. Prenhallindo, tanpa tahun), hal. 19. 


\section{Penyusunan Laporan Keuangan (Dalam Rangka Penyusunan Laporan Tahunan)}

Sesuatu yang berkilauan itu ternyata bukan emas. Pernyataan tersebut menarik dikarenakan pihak manapun juga tidak dapat memberikan suatu penilaian secara mendalam apabila hanya mengetahui tampak luar suatu perusahaan. Apakah sebuah perusahaan itu telah memenuhi ketentuan perundang-undangan yang berlaku, merupakan sebuah perusahaan yang sehat, memiliki kekuatan secara finansial dan manajemen, merupakan perusahaan yang bonafid dengan jaminan perolehan keuntungan setiap tahunnya dan lain sebagainya. Untuk mengetahui kebenaran atas segala sesuatu yang telah diungkapkan di atas dan terlepas dari berbagai macam unsur penipuan, maka salah satu kendaraan yang diperlukan adalah laporan keuangan.

\section{A. Dasar Hukum}

Dasar hukum dari penyusunan laporan tahunan sebagaimana dengan tegas diatur dalam Undang-Undang No. 40 tahun 2007 tentang Perseroan Terbatas (UUPT), yang diterapkan baik pada perusahaan terbuka (tbk) maupun perusahaan tertutup, sebagaimana diatur dalam pasal 56 UUPT, yang menyatakan sebagai berikut:

Dalam waktu 5 (lima) bulan setelah tahun buku perseroan ditutup, direksi menyusun laporan tahunan untuk diajukan kepada RUPS, yang memuat sekurang-kurangnya: 
a. perhitungan tahunan yang terdiri dari neraca akhir tahun buku yang baru lampau dan perhitungan laba rugi dari tahun buku yang bersangkutan serta penjelasan atas dokumen tersebut;

b. neraca gabungan dari perseroan yang tergabung dalam satu grup, disamping neraca dari masing-masing perseroan tersebut;

c. laporan mengenai keadaan jalannya perseroan serta hasil yang telah dicapai;

d. kegiatan utama perseroan dan perubahan selama tahun buku;

e. rincian masalah yang timbul selama tahun buku yang mempengaruhi kegiatan perseroan;

f. nama anggota direksi dan komisaris; dan

g. gaji dan tunjangan lain bagi anggota direksi dan komisaris.

Komunitas pengusaha secara umum telah mengetahui tentang arti penting dari laporan tahunan. Namun, dilain pihak tidak semua pengusaha nasional mengetahui tentang bagaimana penyusunan laporan tahunan. Hal ini mengingat bahwa laporan tahunan adalah dokumen tahunan perusahaan yang berisikan penjelasan informasi perusahaan kepada masyarakat keuangan dan bisnis.

Sementara itu dasar hukum dari penyusunan laporan tahunan sebagaimana dengan tegas diatur dalam Undang-Undang No.40 tahun 2007 tentang Perseroan Terbatas (UUPT), yang diterapkan baik pada perusahaan terbuka (tbk) maupun perusahaan tertutup, sebagaimana diatur dalam Pasal 66 jo. 67 UUPT, yang menyatakan sebagai berikut:

Pasal 66

(1) Direksi menyampaikan laporan tahunan kepada RUPS setelah ditelaah oleh Dewan Komisaris dalam jangka waktu paling lambat 6 (enam) bulan setelah tahun buku Perseroan berakhir.

(2) Laporan tahunan sebagaimana dimaksud pada ayat (1) harus memuat sekurang-kurangnya:

a. laporan keuangan yang terdiri atas sekurangkurangnya neraca akhir tahun buku yang baru lampau dalam perbandingan dengan tahun buku sebelumnya, laporan laba rugi dari tahun 
buku yang bersangkutan, laporan arus kas, dan laporan perubahan ekuitas, serta catatan atas laporan keuangan tersebut;

b. laporan mengenai kegiatan Perseroan;

c. laporan pelaksanaan Tanggung Jawab Sosial dan Lingkungan;

d. rincian masalah yang timbul selama tahun buku yang mempengaruhi kegiatan usaha Perseroan;

e. laporan mengenai tugas pengawasan yang telah dilaksanakan oleh Dewan Komisaris selama tahun buku yang baru lampau;

f. nama anggota Direksi dan anggota Dewan Komisaris;

g. gaji dan tunjangan bagi anggota Direksi dan gaji atau honorarium dan tunjangan bagi anggota Dewan Komisaris Perseroan untuk tahun yang baru lampau.

(3) Laporan keuangan sebagaimana dimaksud pada ayat (2) huruf a disusun berdasarkan standar akuntansi keuangan.

(4) Neraca dan laporan laba rugi dari tahun buku yang bersangkutan sebagaimana dimaksud pada ayat (2) huruf a bagi Perseroan yang wajib diaudit, harus disampaikan kepada Menteri sesuai dengan ketentuan peraturan perundangundangan.

Pasal 67

(1) Laporan tahunan sebagaimana dimaksud dalam Pasal 66 ayat (1) ditandatangani oleh semua anggota Direksi dan semua anggota Dewan Komisaris yang menjabat pada tahun buku yang bersangkutan dan disediakan di kantor Perseroan sejak tanggal panggilan RUPS untuk dapat diperiksa oleh pemegang saham.

(2) Dalam hal terdapat anggota Direksi atau anggota Dewan Komisaris yang tidak menandatangani laporan tahunan sebagaimana dimaksud pada ayat (1), yang bersangkutan harus menyebutkan alasannya secara tertulis, atau alas an tersebut dinyatakan oleh Direksi 
dalam surat tersendiri yang dilekatkan dalam laporan tahunan.

(3) Dalam hal terdapat anggota Direksi atau anggota Dewan Komisaris yang tidak menandatangani laporan tahunan sebagaimana dimaksud pada ayat (1) dan tidak memberi alasan secara tertulis, yang bersangkutan dianggap telah menyetujui isi laporan tahunan.

Kiat tentang bagaimana penyusunan laporan tahunan seperti yang disampaikan oleh Ki Agus Umar Tochfa (Direktur Keuangan PT. ANTAM Tbk.) adalah sebagai berikut: ${ }^{8}$

a. Beberapa perusahaan membuat laporan tahunan meniru laporan mereka sebelumnya atau didasarkan pada format 'klasik'.

b. Laporan tersebut dibuat semata-mata untuk memenuhi kewajiban kepada pasar dan kepada Badan Pengawas Pasar Modal - Bapepam.

c. Bagaimana seharusnya laporan tahunan ditulis?

1. Bahasa yang sederhana?

2. Perlu menyajikan perincian data?

3. Atau laporan tahunan merupakan alat untuk mengembangkan citra perusahaan dan beriklan?

d. Setiap laporan tahunan harus diperlakukan seolah-olah laporan tersebut baru pertama kali ditulis.

e. laporan yang disusun secara sembarang:

1. Mengandung pesan atau persepsi bahwa perusahaan tidak peduli untuk menjalin komunikasi.

2. Perusahaan tidak mengetahui cara untuk melakukannya.

f. Upaya maksimal sudah harus mulai dari tahap perencanaan: pembuatan draft laporan dilakukan sejak dini serta penulisan kerangka acuan sebagai rujukan.

Beliau turut menyampaikan bahwa landasan acuan dibuatnya suatu laporan tahunan adalah berkenaan dengan aspek dari tujuan penyusunan dimaksud. Tujuan dimaksud harus dapat menjawab dua pertanyaan: Apa yang diinginkan untuk diketahui oleh para pembaca

\footnotetext{
${ }^{8}$ Ki Agus Umar Tochfa, Op. Cit., hal. 8.
} 
dan bagaimana pendapat mereka setelah membaca laporan tersebut. Mengingat perusahaan yang dipimpin beliau termasuk salah satu perusahaan terbuka, maka menurutnya tujuan laporan tahunan tersebut adalah untuk memberikan informasi dan menjual saham perusahaan, yaitu dengan tujuan utama: ${ }^{9}$

a. Hal yang penting dari "perusahaan" dan bisnis yang mempunyai prospek masa depan yang cerah.

b. Manajemen memiliki kendali yang kuat.

c. Perusahaan dalam posisi sehat dan kuat.

d. Tantangan yang menghadang telah dapat diidentifikasi.

e. Pemahaman pihak manajemen akan biaya-biaya yang terjadi.

f. Rencana perusahaan untuk mendapatkan penghasilan yang lebih besar di masa depan.

Selanjutnya disampaikan pula bahwa terdapat tujuan khusus yang menjawab keadaan spesifik tertentu pada tahun dimana laporan tersebut disusun: ${ }^{10}$

a. Politik (otonomi daerah, transisi demokrasi).

b. ekonomi (tingginya harga komoditas dunia, lesunya perekonomian, inflasi).

c. industri (teknologi baru, pesaing baru).

d. perusahaan (perubahan strategi, restrukturisasi, ekpansi, peluang, pasar baru, produk baru, peningkatan utang atau ekuitas, litbang, litigasi).

Meskipun secara umum beliau memperggunakan tolok ukur praktek tetapi justru disatu sisi lebih memperkaya khasanah perbandingan antara teori dan praktek. Disamping itu kiat-kiat tersebut disampaikan tidak lain karena laporan tahunan merupakan refleksi dari suatu perusahaan terkait dengan hal dapat dipercaya dengan baik dari segi kejujuran maupun kemampuannya ${ }^{11}$ (baca: bonafiditas); sebagaimana hal tersebut merupakan suatu hal yang mutlak dalam bidang usaha apapun juga. Termasuk pula dengan tingkat kemampuan

${ }^{9}$ Ibid., hal. 8.

${ }^{10}$ Loc. Cit., hal. 8.

11 Kamus Besar Bahasa Indonesia Edisi Kedua, Cet. Ketiga, (Departemen Pendidikan dan Kebudayaan, 1994), hal. 142. 
perusahaan untuk membayar utang-utangnya karena jumlah aktivanya melebihi utang-utang tersebut ${ }^{12}$ (baca: solvabilitas).

Selayaknya suatu laporan tahunan sebagaimana yang dimaksudkan di atas ditandatangani oleh semua anggota direksi dan komisaris, karena laporan ini merupakan bentuk pertanggungjawaban mereka dalam melaksanakan tugasnya. Apabila di antara anggota direksi atau komisaris tidak menandatangani laporan sebagaimana dimaksudkan di atas, harus disebutkan alasannya secara tertulis kepada RUPS agar RUPS dapat menggunakannya sebagai salah satu bahan pertimbangan dalam memberikan penilaian terhadap laporan tersebut. $^{13}$

\section{B. Sistem Standar Akuntansi Keuangan (SAK)}

Pada bagian lain dari laporan tahunan adalah perhitungan tahunan yang harus dibuat sesuai dengan ketentuan Standar Akuntansi Keuangan, yaitu prinsip-prinsip akuntansi yang telah diakui dan disetujui oleh kalangan akuntan Indonesia bersama instansi pemerintah yang berwenang. Apabila standar akuntansi keuangan tersebut tidak dapat dilaksanakan sebagaimana mestinya, maka harus diberikan penjelasan dan alasannya. ${ }^{14}$ Penyerahan perhitungan tahunan mana kepada akuntan publik dilakukan oleh Direksi sebagaimana diatur dalam pasal 59 UU No.1/1995, yang menyatakan:

(1) Direksi wajib menyerahkan perhitungan tahunan perseroan kepada akuntan publik untuk diperiksa apabila:

a. bidang usaha perseroan berkaitan dengan pengerahan dana masyarakat;

b. perseroan mengeluarkan surat pengakuan utang; atau

c. perseroan merupakan perseroan terbuka.

(2) Dalam hal kewajiban sebagaimana dimaksud dalam ayat (1) tidak dipenuhi, perhitungan tahunan tidak boleh disahkan oleh RUPS.

${ }^{12}$ Ibid., hal. 956.

${ }^{13}$ I.G. Rai Widjaya, "Hukum Perusahaan - Undang-undang dan Peraturan-peraturan Pelaksana di Bidang Usaha”, Cet. 1, (Jakarta: Kesaint Blanc, 2000), hal. 266.

${ }^{14}$ Ibid., hal. 267. 
(3) Laporan atas hasil pemeriksaan akuntan publik sebagaimana dimaksud dalam ayat (1) disampaikan secara tertulis kepada RUPS melalui direksi.

(4) Perhitungan tahunan sebagaimana dimaksud dalam ayat (1), setelah mendapat pengesahan RUPS diumumkan dalam 2 (dua) surat kabar harian.

Sementara itu pengaturan dalam UUPT merefleksikan penyerahan perhitungan tahunan mana kepada akuntan publik dilakukan oleh Direksi sebagaimana diatur dalam Pasal 68 jo. 69 UUPT, yang menyatakan:

(1) Direksi wajib menyerahkan laporan keuangan Perseroan kepada akuntan publik untuk diaudit apabila:

a. kegiatan usaha Perseroan adalah menghimpun dan/ atau mengelola dana masyarakat;

b. Perseroan menerbitkan surat pengakuan utang kepada masyarakat;

c. Perseroan merupakan Perseroan Terbuka;

d. Perseroan merupakan persero;

e. Perseroan mempunyai aset dan/atau jumlah peredaran usaha dengan jumlah nilai paling sedikit Rp.50.000.000.000,00 (lima puluh miliar rupiah); atau

f. diwajibkan oleh peraturan perundangundangan.

(2) Dalam hal kewajiban sebagaimana dimaksud pada ayat (1) tidak dipenuhi, laporan keuangan tidak disahkan oleh RUPS.

(3) Laporan atas hasil audit akuntan publik sebagaimana dimaksud pada ayat (1) disampaikan secara tertulis kepada RUPS melalui Direksi.

(4) Neraca dan laporan laba rugi dari laporan keuangan sebagaimana dimaksud pada ayat (1) huruf a, huruf b, dan huruf $c$ setelah mendapat pengesahan RUPS diumumkan dalam 1 (satu) Surat Kabar.

(5) Pengumuman neraca dan laporan laba rugi sebagaimana dimaksud pada ayat (4) dilakukan paling lambat 7 (tujuh) hari setelah mendapat pengesahan RUPS.

(6) Pengurangan besarnya jumlah nilai sebagaimana dimaksud pada ayat (I) huruf e ditetapkan dengan Peraturan Pemerintah.

Pasal 69 
(1) Persetujuan laporan tahunan termasuk pengesahan laporan keuangan serta laporan tugas pengawasan Dewan Komisaris dilakukan oleh RUPS.

(2) Keputusan atas pengesahan laporan keuangan dan persetujuan laporan tahunan sebagaimana dimaksud pada ayat (1) ditetapkan berdasarkan ketentuan dalam Undang-Undang ini dan/atau anggaran dasar.

(3) Dalam hal laporan keuangan yang disediakan ternyata tidak benar dan/atau menyesatkan, anggota Direksi dan anggota Dewan Komisaris secara tanggung renteng bertanggung jawab terhadap pihak yang dirugikan.

(4) Anggota Direksi dan anggota Dewan Komisaris dibebaskan dari tanggung jawab sebagaimana dimaksud pada ayat (3) apabila terbukti bahwa keadaan tersebut bukan karena kesalahannya.

Standar akuntasi keuangan diperlukan mengingat begitu pesatnya informasi dan globalisasi, yang dampaknya turut mempengaruhi perkembangan dunia usaha terutama dalam kaitannya dengan kepentingan dari para pengguna informasi. Sehingga dengan demikian diperlukan adanya suatu metode yang tersendiri, yang secara sedemikian rupa dapat memberikan pemahaman yang komprehensif, yang terkait didalamnya dengan aspek penerimaan dan penggunaan materi informasi tersebut oleh pihak-pihak yang berkepentingan. Pedoman tersebut tidak lain dipergunakan sebagai landasan dalam menyusun dan menyajikan laporan keuangan suatu entitas ekonomi, agar laporan dimaksud seyogyanya dapat dipergunakan, dimengerti, diperbandingkan dan tidak menyesatkan.

Adapun accounting principles dimaksud adalah: ${ }^{15}$

- The rules and conventions adopted or professed as a guide to action.

- A settled ground basis of conduct or practice, refer to as "Generally Accepted Accounting Principles (GAAP)".

- Established by human, not eternal truths, nor basic axioms.

${ }^{15}$ Emil S. Tarigan, Standar Akuntansi Keuangan (Prinsip-Prinsip Akuntansi), disampaikan pada Akuntansi Untuk Praktisi Hukum, LPLIH Jakarta, Mei 2002, hal. 2. 
Merujuk pada prinsip akuntansi tersebut di atas maka terlihat jelas bahwa akuntansi bersifat dinamis sesuai dengan perkembangan ekonomi dan bisnis. Kondisi semacam ini sejalan dengan dinamika hukum sebagai agent of change yang selalu berubah sesuai dengan kebutuhan masyarakat dan segala perubahan maupun perkembangan yang terjadi didalam dunia kemasyarakatan.

Secara umum memperhatikan ketentuan pasal 66 jo. 67 UUPT dan secara khusus pada ketentuan Pasal 68 jo. 69 UUPT secara khusus, maka laporan tahunan yang didalamnya terdapat komponen perhitungan tahunan dapat dikatakan bersifat multidimensi. Dikatakan demikian karena perusahaan memiliki kepentingan sendiri sementara itu pada stakeholder (pemangku kepentingan), baik secara internal maupun eksternal juga memiliki kepentingannya masing-masing. Konteks multidimensi tersebut dapat dicerminkan melaiui keadaan yang sebenarnya dari aktiva, kewajiban, modal dan hasil usaha perseroan. Direksi dan komisaris secara spesifik oleh UUPT dibebankan oleh tanggung jawab penuh akan kebenaran isi perhitungan tahunan perseroan pada khususnya dan laporan tahunan pada umumnya. Stakeholder (pemangku kepentingan) sebagaimana dimaksud di atas selain dari pemegang saham dan manajemen perusahaan juga merupakan para pihak yang berkepentingan terhadap laporan keuangan suatu perusahaan, yaitu: ${ }^{16}$

a. Investor, untuk membantu menentukan keputusan investasinya dan menilai kemampuan perusahaan membayar deviden.

b. Karyawan, untuk menilai kemampuan perusahaan dalam memberikan balas jasa, manfaat pensiun dan kesempatan kerja.

c. Pemberi Pinjaman (Lenders), untuk menilai kemampuan perusahaan dalam hal membayar seluruh pinjaman beserta bunganya.

d. Pemasok dan Kreditur lainnya (Suppliers and Other Trade Creditors), untuk membantu memutuskan apakah jumlah yang terutang dapat dibayar oleh perusahaan pada saat jatuh tempo.

e. Pelanggan (Customer), berkepentingan untuk mengetahui kelangsungan hidup perusahaan.

f. Pemerintah (Government), umumnya berkepentingan untuk aspek pajak dan alokasi sumber daya perusahaan.

g. Masyarakat (Public), untuk mengetahui perkembangan terakhir kesejahteraan perusahaan serta rangkaian aktivitasnya, termasuk

${ }^{16}$ Ibid., hal. 1 . 
kontribusi perusahaan pada perekonomian nasional, jumlah orang yang dipekerjakan dan perlindungan kepada investor domestik.

Terlepas daripada perusahaan telah sepenuhnya menjalankan seluruh ketentuan yang diatur dalam anggaran dasar dan peraturan perundang-undangan yang berlaku, pada prinsipnya laporan tahunan pada suatu perusahaan terbuka adalah penyampaian informasi sesuai prinsip transparansi dan pengungkapan yang tidak lain merupakan pelaksanaan good corporate governance yang akan menciptakan suatu kepercayaan kepada investor dan pada gilirannya menciptakan perbaikan kinerja jangka panjang, serta profit reliability yang pada akhirnya dijabarkan kepada harga saham yang solid dan penghasilan yang mantap, dan juga meningkatkan rating yang menyebabkan bunga pinjaman lebih rendah (cost capital rendah) yang pada akhirnya bermuara memenangkan persaingan usaha. ${ }^{17}$

Kendatipun penerapan prinsip dimaksud semestinya tidak jauh berbeda dengan perusahaan tertutup. Oleh karenanya dalam upaya untuk meminimalisasi dampak-dampak negatif, perusahaanperusahaan semestinya mengembangkan suatu program kerja dan anggaran untuk periode 5 (lima) tahun mendatang yang telah terlebih dahulu ditetapkan oleh para pemegang saham pada saat dilaksanakannya RUPS. Program kerja dan anggaran dimaksud akan memuat: ${ }^{18}$

a. rencana kerja yang terperinci;

b. target, strategi bisnis, kebijakan dan program kerja;

c. anggaran yang disusun secara terperinci; dan

d. proyeksi keuangan dan hal-hal lainnya yang ditetapkan oleh RUPS.

${ }^{17} \mathrm{Ki}$ Agus Umar Tochfa, Op. Cit., hal. 60.

${ }^{18}$ Syarif Bastaman, Junaidi, dan Ari Wahyudi Hertanto of Bastaman \& Partners, Indonesia: How to Implement Good Corporate Governance, International Financial Law Review 2003, (London: PW Reproprint Ltd., 2003), hal. 115. 


\section{Proses Akuntansi ${ }^{19}$}

Beberapa hal penting yang harus diperhatikan dalam proses akuntansi adalah sebagai berikut:

a. Fakta yang dicatat, meliputi:

(1) Angka-angka atau jumlah yang dicantumkan atau dilaporkan dalam pos Neraca dan perhitungan rugi laba merupakan kumpulan dan ringkasan dari catatan historis, yaitu peristiwa yang benar-benar telah terjadi;

(2) Nilai uang yang dilaporkan didasarkan atas harga yang benar-benar terjadi di masa lalu, bukan nilai sekarang atau nilai likuidasinya.

b. Prinsip dan Kebiasaan Akuntansi (Accounting Convention and Postulate), yang meliputi:

1. Aturan Dasar Akuntansi, yang meliputi:

(a) The Business (Acoounting) Entity Concepts, yaitu memuat hal-hal sebagai berikut:

- harus ditentukan batas-batas (ruang lingkup) dari kegiatan akuntansi dan laporan;

- dengan dasar bahwa akuntansi melaporkan posisi keuangan perusahaan maka harus dilakukan atas transaksi yang dilakukan oleh perusahaan, bukan pemilik atau kreditur, atau pihak lain.

(b) The Going Concern, yaitu memuat hal-hal sebagai berikut:

- perusahaan diasumsikan akan berlangsung untuk waktu yang tidak ditentukan batasnya;

- aktiva dalam neraca dicantumkan adalah original cost bukan nilai likuidasi (cost of replacement).

(c) The Unit of Measurement Concept, yaitu memuat hal-hal sebagai berikut:

- proses akuntansi mulai dari mencatat, menggolongkan, mengklasifikasi dan melaporkan transaksi perusahaan harus

${ }^{19}$ Prio Trisnoprasetio, Divisi Pendidikan dan Latihan, DPP SPI, Makalah Membaca Laporan Keuangan. 
dilakukan dalam jumlah yang diukur atau dinyatakan dengan satuan mata uang (Rp., US\$, Euro, Yen, dan lain sebagainya);

- untuk beberapa hal misalnya administrasi gudang dapat menggunakan satuan ton, $\mathrm{Kg}$, Meter, dan sebagainya.

(d) The Cost Consepts, yaitu memuat hal-hal sebagai berikut:

- data akuntansi harus dicatat menurut harga perolehan (cost), yaitu harga pada saat terjadinya transaksi;

- harga perolehan adalah semua pengeluaran yang terjadi untuk memperoleh dan menempatkan aktiva dalam kondisi siap dipergunakan oleh perusahaan;

- diukur dengan dasar tunai atau ekivalen tunai.

(e) The Realization Concept, yaitu pendapatan dapat diakui untuk dicatat dan dilaporkan bila proses penjualan telah selesai atau jasa telah dilaksanakan.

(f) Stable of the Unit of Measurement Concept, yaitu jumlah yang dilaporkan tidak boleh dipengaruhi oleh fluktuasi harga.

2. Aturan Pokok Praktek Akuntansi

(a) Time Period Concept, yaitu sejalan dengan Going Concern Concept, maka aktivitas dinyatakan untuk jangka waktu tidak terbatas dan proses pelaporan dipecah-pecah untuk periode waktu tertentu (basic accounting period).

(b) The Disclosure Concept, yaitu menghendaki agar segala sesuatu yang cukup materiil dan relevan diungkap dengan lengkap dalam laporan keuangan, misalnya adanya pembatasan pembayaran dividen, atau kejadian setelah neraca (subsequent event) atau adanya aktiva yang dijadikan jaminan atas pinjaman, dan sebagainya.

(c) The Objective Evidence Concept, yaitu pencatatan transaksi harus berdasarkan bukti yang objektif, yaitu bukti yang paling sedikit dipengaruhi oleh pendapat pribadi.

(d) The Consistency Concept, yaitu memuat hal-hal sebagai berikut: 
- prinsip akuntansi diterapkan secara konsisten dari periode ke periode;

- Perubahan atas prinsip akuntansi yang dipergunakan harus diungkapkan dan dijelaskan pengaruhnya terhadap laporan periode yang bersangkutan.

(e) The Conservatism Concept, yaitu akuntansi telah mencatat dan menghitung kerugian yang mungkin terjadi, tetapi tidak mencatat laba yang belum terjadi.

(f) The Matching Concept, yaitu memuat hal-hal sebagai berikut:

- dikenal sebagai the matching concept of revenue and cost concept;

- penentuan laba mempertemukan pendapatan yang direalisasi dengan biaya yang diperlukan untuk memperoleh pendapat tersebut untuk periode yang sama.

c. Pendapat Pribadi (Personal Judgment)

(1) Dalam menerapkan prinsip akuntansi masih diberikan keleluasan untuk mengadakan penilaian berdasarkan pendapat pribadi, seperti dalam hal:

a. mencatat nilai persediaan yang harus berdasarkan harga perolehan, dapat memilih metode FIFO (First In First Out - suatu metode penilaian dan pengidentifikasian persediaan barang yang digunakan atau dijual dengan cara barang yang terakhir diterima atau dibeli dianggap sebagai yang pertama digunakan atau dijual. Jika dipergunakan untuk penilaian persediaan, maka persediaan akhir diasumsikan sebagai barang yang diproduksi atau dibeli paling awal), LIFO (Last In First Out - suatu metode penilaian dan pengidentifikasian persediaan barang yang digunakan atau dijual dengan cara barang yang terakhir diterima atau dibeli dianggap sebagai yang pertama digunakan atau dijual. Jika dipergunakan untuk penilaian persediaan, maka persediaan akhir diasumsikan sebagai barang yang diproduksi atau dibeli paling awal) atau average cost; 
a) menaksir usia aktiva;

b) memilih metode penyusutan straigh line atau declining method;

c) mencadangkan kerugian atas piutang; balance sheet atau income approach.

(2) Pendapat pribadi sangat tergantung dari kemampuan dan integritas pembuatnya;

(3) Penggunaan judgment ini dibenarkan asalkan tetap dalam ruang lingkup prinsip akuntansi yang diperkenankan dan dilakukan secara konsisten, setiap perubahan harus dinyatakan sehingga pihak-pihak yang membacanya dapat mengerti dalil mana yang dipergunakan.

\section{Laporan Keuangan}

Akuntansi secara definisi disebutkan sebagai teori dan praktek perakunan, termasuk tanggung jawab, prinsip, standar kelaziman (kebiasaan) dan semua kegiatannya; atau seni pencatatan dan pengikhtisaran transaksi keuangan dan penafsiran akibat suatu transaksi terhadap suatu kesatuan ekonomi. $^{20}$ Selain itu akuntansi (accounting) seting disebut sebagai Language of Business karena fungsinya sebagai kegiatan yang menyediakan informasi kuantitatif tentang suatu entitas ekonomi untuk pengambilan keputusan bagi semua pihak yang berkepentingan (accounting is the process of identifying, measuring, and communicating economic information to permit informed judgments and decisions by users of information $)^{2122}$

${ }^{20}$ Kamus Besar Bahasa Indonesia, Op. Cit., hal. 21.

${ }^{21}$ Emil S. Tarigan, Op. Cit., hal. 1.

${ }^{22}$ Menurut Black's Law Dictionary Seventh Edition, p.12, Accounting is an act or system of making up or settling accounts, consisting of a statement of account with debits and credits arising from relationship of parties. Rendition of an account, either voluntarily or by order of the court. In the latter case, it imporis a rendition of judgment for the balance ascertained to be due. The term may include payment of the amount due. - in partnership law, is equitable proceeding for a complete settlement of all partnership affairs. 


\section{A. Proses Akuntansi ${ }^{23}$}

Proses akuntansi adalah mengolah informasi kuantitatif tentang keuangan suatu perusahaan (quantitative financial information) dari mulai bukti dasar transaksi sampai dengan laporan keuangan. Bidang akuntansi yang mengolah informasi keuangan guna menghasilkan laporan keuangan disebut akuntansi keuangan (financial accounting).

Secara garis besar, proses akuntansi dilakukan dengan tahapan berikut:

- Proses pencatatan (recording phase) yang meliputi:

- Persiapan atau penerimaan bukti/dokumen transaksi;

- Pencatatan bukti transaksi kedalam berbagai buku harian secara kronologis;

- Klasifikasi posting transaksi kedalam berbagai account dalam general ledger dan subsidiary ledger.

Dalam penyusunan laporan keuangan tersebut dipergunakan pola asumsi dasar akuntansi (underlying assumption), dimana melalui asumsi dasar/konsep dasar yang mendasari penyusunan laporan keuangan adalah: ${ }^{24}$

a. Kelangsungan usaha (going concern)

suatu entitas ekonomi diasumsikan terus melakukan usahanya scara berkesinambungan tanpa maksud dibubarkan, karena itu perusahaan diasumsikan tidak bermaksud melikuidasi atau mengurangi secara material skala usahanya. Jika keinginan itu ada, tentunya laporan keuangan harus disusun dengan dasar yang berbeda.

b. Dasar accrual (accrual basis)

Pengukuran aktiva, kewajiban, pendapatan, beban serta perubahannya diakui pada saat terjadi, bukan pada saat uangnya diterima atau dibayarkan. Laporan keuangan yang disusun atas dasar accrual menyajikan informasi bukan hanya transaksi kas masa lalu, tetapi juga kewajiban pembayarannya di masa depan dan sumber daya yang akan diterima di masa depan. Dengan cara ini, laporan keuangan akan mencakup informasi transaksi masa lalu dan peristiwa lainnya, yang diharapkan akan bermanfaat bagi pengguna informasi dalam pengambilan keputusan ekonomi.

\footnotetext{
${ }^{23}$ Op. Cit., hal. 3 .

${ }^{24}$ Ibid., hal. 3 .
} 


\section{B. Transaksi ${ }^{25}$}

Apabila berbicara tentang transaksi, maka perlu untuk diketahui bahwa transaksi menurut proses akuntansi adalah suatu peristiwa atau tindakan perusahaan yang mengakibatkan terjadinya perubahan dalam struktur asset, liabilities dan/atau equity, dimana didalamnya dikenal 2 (dua) jenis transaksi, yaitu:

a. Transaksi usaha (business transaction), yaitu transaksi antara perusahaan dengan pihak lain (outsiders).

b. Transaksi internal (internal transaction), pemindahan biaya dalam suatu perusahaan, misalnya proses produksi (pemindahan bahan/persediaan pembebanan upah dan pembiayaan overhead)

Dalam pencatatan transaksi, selalu dilakukan identifikasi pengaruh transaksi tersebut terhadap asset, liabilities dan/atau equity. Identifikasi ini mengacu kepada prinsip Basic Accounting Equation, yaitu:

\section{ASSET = LIABILITIES + OWNER'S EQUITY}

Dalam proses akuntansi, dilakukan identifikasi dampak setiap transaksi terhadap asset, liabilities dan equity tersebut, dalam bentuk mekanisme pendebitan (D0 dan pengkreditan (K).

Setiap unsur asset, liabilities dan equity dirinci dalam tiap account" secara individual. Kumpulan dari account inilah yang disebut sebagai "General Ledgers".

Untuk account atas unsur asset, liabilities dan equity tertentu (misalnya piutang usaha, persediaan dan hutang dagang), diperlukan catatan rincian lebih lanjut, yang dibuat per individu (nama atau jenis barang). Kumpulan account individu sebagai kontrol atas unsur asset, liabilities dan equity tertentu ini disebut Subsidiary Ledgers.

Account biaya dan pendapatan hakekatnya merupakan bagian dari account equity yang pada akhir tahun digabungkan secara net kedalam saldo laba atau modal.

\section{Output Proses Akuntansi}

Output utama yang dihasilkan oleh proses akuntansi adalah "Laporan Keuangan" yang lazimnya terdiri dari: ${ }^{26}$

${ }^{25}$ Loc. Cit., hal. 3-4. 
a. Neraca, laporan yang menggambarkan posisi keuangan perusahaan pada saat tertentu. Oleh karenanya neraca menggambarkan sumber-sumber ekonomi yang dimiliki, kewajiban-kewajiban dan modal perusahaan.

b. Laporan laba rugi, laporan yang menunjukkan kinerja (hasil usaha) perusahaan selama periode waktu tertentu. Oleh karenanya, laporan ini memperlihatkan jumlah pendapatan dan jumlah beban-beban (biaya) serta sisa hasil usaha selama satu periode.

c. Laporan perubahan modal, atau laporan laba yang ditahan, laporan laba yang ditahan merupakan laporan yang menunjukkan akumulasi laba yang tersimpan diperusahaan untuk tujuan dibagikan kepada pemegang saham atau untuk pengembangan perusahaan di masa yang akan datang.

d. Laporan arus kas, atau laporan arus dana, adalah laporan yang mengikhtisarkan sumber-sumber penerimaan dan pengeluaran dalam arti kas, suatu unit usaha slama satu periode tertentu (yaitu periode yang sama dengan laporan laba rugi).

e. Catatan dan materi penjelasan lain yang merupakan bagian integral dari laporan keuangan.

\section{Karakteristik Kualitatif Laporan Keuangan Perseroan Terbatas}

Bagian ini lebih menonjolkan pada konteks perumusan laporan keuangan yang lebih menekankan pada aspek manfaat dan pemahaman yang mendalam bagi para pihak yang berkepentingan. Karakteristik kualitatif ini juga dipandang sebagai suatu ciri khas perumusan informasi dalam laporan keuangan.

Ada 4 (empat) karakteristik pokok, yaitu: ${ }^{27}$

1. Dapat dipahami (understandability)

Informasi dalamlaporan keuangan hendaknya mudah dipahami oleh users. Untuk maksud ini, users diasumsikan memiliki pengetahuan yang memadai tentang aktivitas ekonomi dan bisnis, juga tentang akuntansi serta memiliki kemampuan untuk mempelajari informasi dengan ketekunan yang wajar.

${ }^{26}$ Ibid., hal. 1.

${ }^{27}$ Ibid, hal.7-9. 


\section{Relevansi (relevance)}

Informasi yang disajikan dalam laporan keuangan haruslah relevan untuk memenuhi kebutuhan users dalam proses pengambilan keputusan. Informasi dapat dikatakan relevan apabila dapat mempengaruhi users dalam pengambilan keputusan ekonomi dengan membantu untuk mengevaluasi peristiwa masa lalu, masa kini, atau masa depan.

Materialitas, relevansi informasi acapkali dipengaruhi oleh aspek hakekat dan materialitasnya. Suatu informasi dipandang material apabila kelalaian untuk mencantumkan atau kesalahan dalam mencatat informasi tersebut dapat mempengaruhi keputusan ekonomi yang diambil ole users atas suatu laporan keuangan.

\section{Keandalan (reliability)}

Agar bermanfaat, informasi dalam laporan keuangan juga harus andal (reliable). Informasi dianggap memiliki kualitas yang andal jika bebas dari pengertian yang menyesatkan, bebas dari kesalahan material, dan dapat diandalkan oleh users sebagai penyajian yang jujur (faithful representation) yang mencakup semua informasi yang seharusnya disajikan. Dalam karakteristik keandalan ini terdapat 6 (enam) faktor yang perlu diperhatikan, yaitu: ${ }^{28}$

\section{(a) Penyajian jujur (faithful representation)}

Informasi dalam laporan keuangan haruslah menggambarkan dengan jujur transaksi serta peristiwa lain yang seharusnya disajikan, atau yang secara wajar dapat diharapkan untuk disajikan, misalnya neraca, harus menggambarkan dengan jujur semua transaksi serta peristiwa lainnya dalam bentuk aktiva, kewajiban, dan ekuitas yang seharusnya ada pada tanggal pelaporan.

(b) Substansi mengungguli bentuk (substance over form) Substansi transaksi atau peristiwa lain, tidak selalu konsisten dengan apa yang tampak dari bentuk hukum. Oleh karena itu semua transaksi dan peristiwa lain,

${ }^{28}$ Loc. Cit., hal. 8 . 
hendaknya dicatat dan disajikan dengan jujur sesuai dengan substansi dan realitas ekonomi, bukan hanya bentuk hukumnya.

(c) Netralitas (neutrality)

Informasi dalam laporan keuangan harus diarahkan kepada kebutuhan semua users dan tidak boleh disajikan untuk keuntungan beberapa pihak tertentu.

(d) Pertimbangan sehat (prudence)

Pertimbangan sehat yang mengandung unsur kehati-hatian harus diutamakan dalam penyusunan laporan keuangan. Dalam hal ini hendaknya aktiva atau penghasilan tidak dinyatakan terlalu tinggi dan kewajiban atau beban tidak dinyatakan terlalu rendah. Pertimbangan sehat ini sangat berperan dalam menghadapi ketidakpastian suatu peristiwa atau keadaan tertentu, misalnya penentuan kolektibilitas piutang, prakiraan masa manfaat aktiva tetap, dan tuntutan atas jaminan garansi yang mungkin timbul.

(e) Kelengkapan (completeness)

Agar dapat diandalkan, informasi dalam laporan keuangan harus lengkap. Kesengajaan untuk tidak mengungkapkan sesuatu (omission), mengakibatkan informasi menjadi tidak benar atau menyesatkan, sehingga tidak dapat diandalkan.

\section{(f) Tepat waktu (timeliness)}

Faktor ini merupakan kendala terhadap informasi yang relevan dan andal. Untuk menyediakan informasi tepat waktu, seringkali laporan keuangan belum dapat mencakup seluruh aspek transaksi, sehingga mengurangi keandalan informasi. Sebaliknya jika laporan ditunda sampai seluruh aspek diketahui, informasi tersebut menjadi kurang relevan karena telah lewat waktu.

\section{Dapat dibandingkan (comparability)}

Users seharusnya dapat memperbandingkan laporan keuangan perusahaan antar periode untuk mengidentifikasi kecenderungan (trend) posisi dan kinerja keuangan. Users juga hendaknya dapat memperbandingkan laporan keuangan 
antar perusahaan untuk mengevaluasi posisi keuangan, kinerja serta perubahan posisi keuangan secara relatif.

Implikasi penting dari karakteristik kualitatif adalah bahwa users (para pengguna) seharusnya mendapat informasi tentang konsistensi kebijakan akuntansi yang digunakan dalam penyusunan laporan keuangan.

\section{E. Keterbatasan Laporan Keuangan}

Laporan keuangan secara umum mempunyai keterbatasan, antara lain:

a. Bersifat historis, laporan keuangan merupakan laporan antas kejadian atau peristiwa yang sudah lewat, sehingga tidak dapat dijadikan satu-satunya alat dalam proses pengambilan keputusan.

b. Bersifat umum, laporan keuangan dimaksudkan untuk memenuhi kebutuhan pihak tertentu, tetapi semua user secara umum.

c. Pertimbangan materialitas, laporan keuangan hanya mengungkapkan informasi keuangan yang material, sehingga suatu fakta yang dianggap tidak material tidak akan dilaporkan.

d. Pertimbangan sehat, penyusunan laporan keuangan tidak luput dari penggunaan taksiran dan penerapan pertimbangan kehatihatian dalam menghadapi ketidakpastian transaksi.

e. Bersifat konservatif, lazimnya dipilih alternatif laba bersih yang paling kecil.

\section{F. Daftar Istilah ${ }^{29}$}

Berikut ini adalah beberapa istilah yang umum dipergunakan dalam penyusunan laporan keuangan sebagai referensi tambahan guna membantu dalam menganalisis maupun mengevaluasi laporan pada sebuah perseroan terbatas, antara lain adalah:

a. Aktiva, adalah sumber daya yang :

${ }^{29}$ Basyiruddin Nur, Accounting for Lawyer, disampaikan pada Pendidikan Khusus Profesi Advokat di Fakultas Hukum Universitas Indonesia - 2005. 
(1) Dikendalikan oleh perusahaan sebagai akibat peristiwa lalu.

(2) Bagi perusahaan diharapkan akan menghasilkan manfaat ekonomis dimasa depan.

b. Investasi Lancar, adalah investasi yang dapat segera dicairkan dan dimaksudkan untuk dimiliki selama setahun atau kurang.

c. Investasi Jangka Panjang, adalah investasi selain investasi lancar.

d. Persediaan, yaitu aktiva yang :

(1) Tersedia untuk dijual dalam kegiatan usaha normal;

(2) Dalam proses produksi dan atau dalam perjalanan; atau

(3) Dalam bentuk bahan atau perlengkapan (supplies) untuk digunakan dalam proses produksi atau pemberian jasa.

e. Laporan Keuangan Interim, yaitu laporan keuangan yang diterbitkan diantara dua laporan keuangan tahunan.

f. Laporan Keuangan Konsolidasi, yaitu suatu laporan keuangan dari suatu grup perusahaan yang disajikan sebagai satu kesatuan ekonomi.

g. Depresiasi/penyusutan, yaitu alokasi jumlah suatu aktiva yang dapat disusutkan sepanjang masa manfaat yang diestimasi. Penyusutan untuk periode akuntansi dibebankan ke pendapatan langsung.

h. Amortisasi, yaitu alokasi sistematis dari nilai aktiva tidak berwujud yang dapat didepresiasi selama masa manfaat aktiva tersebut.

i. Nilai Wajar (fair value), yaitu suatu jumlah yang dapat digunakan sebagai dasar pertukaran aktiva atau penyelesaian kewajiban antara pihak yang paham dan berkeinginan untuk melakukan transaksi wajar.

j. Nilai Pasar, yaitu jumlah yang dapat diperoleh dari penjualan suatu investasi dalam pasar yang aktif.

k. Agio Saham/premi, yaitu selisih lebih dimana harga pasar saham lebih besar dari harga nominalnya.

1. Disagio Saham/diskon, yaitu Selisih kurang dimana harga pasar saham lebih kecil dari harga nominalnya.

m. Stock Split, yaitu pemecahan nilai nominal per lembar saham.

n. Hak Minoritas, yaitu bagian hasil usaha dan bagian aktiva neto dari anak perusahaan yang tidak dimiliki baik secara langsung maupun tidak langsung oleh induk perusahaan. 
o. Kontinjensi, yaitu merupakan suatu kondisi atau situasi, dengan hasil akhir berupa keuntungan atau kerugian, yang baru dapat dikonfirmasikan setelah terjadinya atau tidak terjadinya peristiwa yang tidak pasti terjadi dimasa depan.

p. Sub Sequent Event, yaitu peristiwa yang terjadi antara tanggal neraca dan tanggal penerbitan laporan keuangan.

q. Pihak-pihak yang Mempunyai Hubungan Istimewa, yaitu dengan memperhatikan ketentuan yang terdapat dalam PSAK, yang dimaksud mempunyai dengan pihak yang mempunyai hubungan istimewa adalah :

1) perusahaan yang melalui satu atau lebih perantara, mengendalikan, atau dikendalikan oleh atau berada di bawah pengendalian bersama, dengan perseroan pelapor;

2) perusahaan asosiasi;

3) perorangan yang memiliki, baik secara langsung maupun tidak langsung, suatu kepentingan hak suara si perusahaan pelapor yang berpengaruh secara signifikan, dan anggota keluarga dekat dari perorangan tersebut (yang dimaksudkan dengan anggota keluarga dekat adalah mereka yang dapat diharapkan mempengaruhi dan dipengaruhi perorangan tersebut dalam transaksinya dengan perusahaan pelapor);

4) karyawan kunci, yaitu orang-orang yang mempunyai wewenang dan tanggung jawab untuk merencanakan, memimpin, dan mengendalikan kegiatan perusahaan pelapor yang meliputi anggota dewan komisaris, direksi dan manajer dari perusahaan serta anggota keluarga dekat orangorang tersebut; dan

5) perusahaan di mana suatu kepentingan substansial dalam hak suara dimiliki baik secara langsung maupun tidak langsung oleh setiap orang yang diuraikan dalam butir (3) dan (4), atau setiap orang tersebut mempunyai pengaruh signifikan atas perusahaan tersebut. Ini mencakup perusahaanperusahaan yang dimiliki anggota dewan komisaris, direksi dan pemegang saham utama dari perusahaan pelapor dan perusahaan-perusahaan yang 
mempunyai anggota manajemen kunci yang sama dengan perusahaan pelapor.

\section{Arti Penting Ahli/Praktisi Hukum untuk Berkemampuan Membaca Laporan Keuangan}

Semangat dasar dari didirikannya sebuah perseroan terbatas adalah untuk make money (mencari keuntungan sebesar-besarnya). Artinya dalam hal ini aspek komersil merupakan jantung dari sebuah perusahaan. Tapi apa korelasi dan kepentingan dari para ahli/praktisi hukum terhadap transaksi tersebut merupakan satu hal yang dapat dikaji secara ringan dan sederhana. Secara umum beberapa hal yang dapat diangkat sebagai bahan pertimbangan tentang arti penting bagi para ahli/praktisi hukum untuk memiliki kemampuan membaca laporan keuangan kiranya antara lain meliputi:

1. agar memiliki suatu gambaran dan/atau pemahaman terhadap transaksi-transaksi yang dilakukan oleh sebuah perusahaan pada waktu tertentu;

2. memahami tentang aspek-aspek umum akuntansi dan dapat mengetahui bahwa produk akhir dari suatu proses atau kegiatan akuntansi dalam kesatuan akuntansi usaha, yang dilakukan menurut tata cara (standar) tertentu;

3. menyatakan tentang harta kekayaan dan hutang perusahaan, yang kemudian dikaitkan dengan aspek-aspek legal tentang bagaimana diperolehnya aset dan bagaimana terjadinya utang perusahaan (perseroan terbatas) dimaksud, sehingga dapat diketahui aspek legalitas dari kekayaan maupun utang dimaksud;

4. memahami aspek historis transaksi komersil sebuah perusahaan;

5. dapat melakukan ataupun memiliki suatu pemahaman terhadap transaksi-transakasi yang tidak wajar yang dilakukan oleh perusahaan dalam menjalankan kinerja usahanya, sehingga dapat ditelusuri apakah transaksi tersebut terjadi dikarenakan sebagai suatu pertimbangan bisnis semata, ketidakhati-hatian perusahaan atau transaksi dimaksud memang secara sengaja dilakukan;

6. memahami struktur, kinerja maupun kesehatan dari sebuah perusahaan;

7. mengingat dan memperhatikan ketentuan Pasal $6 \mathrm{KUH}$ Dagang, tentang kewajiban perusahaan untuk memelihara pembukuan;

8. sebagai salah satu sumber data dalam pembuatan legal due diligence (penyusunan laporan pemeriksaan atau penyusunan laporan uji tuntas dari segi hukum) atas suatu perseroan terbatas; 
9. dan lain sebagainya.

Sebelum dibahas lebih lanjut, terdapat permasalahan yang umum timbul dalam penyusunan laporan keuangan. Kondisi mana dikarenakan tidak semua perusahaan berbentuk perseroan terbatas memiliki instrumen laporan keuangan yang baku. Tidak jarang metode yang dipergunakan hanya dengan menggunakan pembukuan arus kas yang sifatnya sangat sederhana. Oleh karenanya hampir dapat dikatakan bahwa tidak semua perusahaan perseroan terbatas menerapkan standar akuntasi keuangan. Asumsi yang dipergunakan adalah banyak perusahaan perseroan terbatas yang didirikan dengan modal minimum sebagaimana yang diatur dalam UUPT.

Artinya tidak semua perusahaan berbentuk perseroan terbatas memiliki atau bahkan memahami arti penting dari sebuah laporan keuangan. Mengingat dan memperhatikan bahwa tidak semua perusahaan berbentuk perseroan terbatas tersebut memiliki pemahaman tentang standar akuntansi keuangan, melainkan tidak jarang yang hanya mempergunakan pola-pola pembukuan sederhana dan konservatif. Hal ini tidak lain dikarenakan kultur berbisnis pada masyarakat asia berbeda dengan masyarakat barat, dimana masyarakat asia lebih menekankan pada bagaimana mengembangkan bisnisnya (bahkan berpatokan pada prinsip by any means necessary), yang justru kebalikan dari kultur barat yang lebih menekankan pada aspek legalitas yang mengiringi kinerja komersilnya. Perbedaan sederhana ini merupakan dasar penting yang harus diketahui oleh para ahli/praktisi hukum.

Sebagaimana yang telah kita ketahui bersama bahwa laporan keuangan terhadap suatu perusahaan disusun dengan menggunakan standar akuntansi keuangan, dimana dalam hal ini penyusunan tersebut dapat ditangani secara internal maupun oleh para profesional yang berprofesi sebagai akuntan publik, yang kesemuanya dikembalikan pada kebutuhan para stakeholder (pemangku kepentingan). Ahli/praktisi hukum secara umum tidak memiliki pengetahuan yang khusus dan mendalam tentang menyusun suatu laporan keuangan, tetapi dalam menjalankan aktivitas profesinya pengetahuan tentang laporan keuangan tersebut merupakan suatu hal yang perlu dimiliki. Pengetahuan mana merupakan bekal dalam memahami pengelolaan aset-aset perusahaan, kewajiban perusahaan terhadap pihak ketiga, bentuk-bentuk transaksi dan lain sebagainya, yang kemudian ditelaah sampai seberapa jauh transaksi-transaksi tersebut sah dan dibenarkan oleh peraturan perundangundangan yang berlaku. Tidak jarang hal tersebut juga terjadi dalam lingkup perpajakan.

Lazimnya analisis terhadap laporan keuangan sebuah perusahaan dilakukan dalam rangka proses legal due diligence (penyusunan laporan pemeriksaan atau penyusunan laporan uji tuntas dari segi hukum). Meskipun demikian pada pelaksanaannya tidak jarang dijumpai kesulitan dalam 
pemahaman baik dikarenakan keterbatasan pengetahuan maupun dikarenakan adanya penyembunyian informasi dan kemungkinankemungkinan lainnya dikarenakan faktor kerahasiaan, yang mengakibatkan para ahli/praktisi hukum tidak dapat melakukan penetrasi terhadap informasi keuangan dimaksud, atau bahkan sebaliknya ahli/praktisi hukum tersebut dengan sengaja tidak membuka informasi tersebut (misalnya kepada Bapepam).

Dalam proses penyusunan laporan pemeriksaan hukum atau penyusunan laporan uji tuntas tersebut, salah satu prosedur yang dilakukan adalah memeriksa perjanjian kredit, transaksi, piutang dan berbagai aspek keuangan yang memiliki dampak pada lingkup legalitas maupun lalu lintas hukum dengan pihak ketiga dari perusahaan yang diaudit. Para ahli/praktisi hukum dalam menjumpai kasus ketidaksinkronan informasi yang tercermin dalam laporan keuangan, secara umum tidak akan secara eksplisit memberikan suatu kepastian yang didasarkan atas asumsi tanpa disertai keberadaan kualifikasi/disclaimer yang melekat pada hasil pemeriksaan dimaksud. Oleh karenanya secara prinsip para praktisi hukum sebaiknya memiliki pengetahuan yang memadai tentang laporan tahunan secara umum dan laporan keuangan secara khusus. Alternatif lain yang dapat dilakukan adalah dengan meminta pihak yang memiliki keahlian khusus seperti halnya akuntan publik untuk saling berkoordinasi dalam menangani pekerjaan dimaksud.

Laporan keuangan dalam praktek berbisnis pada perusahaan yang berbasis perseroan terbatas, khususnya terhadap penerapan standar akuntasi keuangan, lebih banyak diterapkan oleh perusahaan kelas menengah ke atas. Terutama dilakukan oleh listed companies, yang salah satunya adalah dalam rangka transparansi ke publik terhadap kesehatan keuangan perusahaan, yang secara otomatis akan berkaitan erat dengan bagaimana pengelolaan dan kinerja perusahaan yang bersangkutan. Dampak yang diberikan adalah untuk memberikan kenyamanan akan rasa aman dari para stakeholder perusahaan yang dimaksud. Fungsi dan kedudukan dari para ahli/praktisi hukum, yang dalam hal ini bersinergi dengan profesi keuangan terkait, adalah untuk memastikan bahwa secara hukum laporan keuangan yang terefleksikan tersebut bukan semata kepastian semu, melainkan suatu kepastian yang memiliki reliabilitas dan akuntabilitas yang pasti dari sisi hukum.

Titik berat tulisan ini adalah tidak melulu pada aspek hukum perusahaannya saja, melainkan berupaya sedemikian rupa untuk mengetengahkan suatu hal yang agak lebih mendalam dengan melakukan pembahasan terhadap pengetahuan seputar standar profesi yang berada dibalik suatu penyusunan laporan keuangan Meskipun dipandang sebagai suatu bidang maupun profesi yang berbeda, tetapi faktor simbiose 
mutualisme sangat sarat dan melekat erat antar kedua bidang ini, dimana satu sama lain saling dukung dan tunjang.

\section{Penutup}

1. Selayaknya ahli/praktisi hukum, profesi akuntan juga merupakan salah satu profesi yang penting dikarenakan keahliannya, dimana perlu untuk dibangun sinergi konstruktif antara keduanya dapat menciptakan suatu pertumbuhan ekonomi positif, sehat, profitable, prospektif dan lain sebagainya. Namun, dibalik itu tanpa ditunjangnya penegakkan hukum, maka akan sangat rentan dengan unsur penipuan (fraud), yang mengakibatkan merosotnya moral perekonomian bangsa.

2. Para praktisi hukum seyogyanya telah memiliki pengetahuan yang memadai tentang pemahaman terhadap suatu laporan tahunan dan/atau laporan keuangan. Dalam arti dapat memahami aspekaspek yang berkenaan dengan assets, liabilities dan equity, serta dapat memahami pola dan alur transaksi, oleh karenanya melalui uraian singkat dan sederhana ini sekiranya dapat memberikan suatu pemahaman dasar tentang sistematika maupun prosedur umum dalam bidang akuntansi keuangan pada perusahaan berbentuk perseroan terbatas, yang kemudian dikaitkan dengan aspek legalitas yang melatarbelakanginya.

3. Semakin maju dunia teknologi dan perkembangan yang pesat dibidang informatika, maka sudah barang tentu akan mempengaruhi kinerja suatu perusahaan, dimana dalam menyikapi segala perkembangan yang terjadi diharapakan tidak hanya terfokus pada ahli/praktisi hukum saja, melainkan kepada para aparat penegak hukum dan terlebih pada perangkat peraturan perundang-undangan untuk dapat mengikuti atau mengejar pertumbuhan bidang ekonomi, hukum dan informasi dimaksud.

4. Doktrin-doktrin modern dibidang hukum perusahaan yang berkembang bertujuan untuk memberikan suatu panduan terhadap perusahaan-perusahaan dalam mengimplementasikan pembukuannya, dan oleh karenanya turut diharapkan undangundang beserta seluruh perangkat peraturan pendukung lainnya dapat memberikan suatu kepastian hukum dan menunjukan upayaupaya konkrit terutama dalam aspek penegakkan hukumnya, dalam menghadapi. kasus-kasus pelanggaran yang terjadi dikarenakan ketidak benaran/kebohongan laporan tahunan, 
penipuan, penggelapan dan lain sebagainya, yang mengakibatkan dampak kerugian baik bagi masyarakat maupun negara. 


\section{Daftar Pustaka}

Bastaman, Syarif, Junaidi, dan Ari Wahyudi Hertanto of Bastaman \& Partners, Indonesia: How to Implement Good Corporate Governance, International Financial Law Review 2003, PW Reproprint Ltd, London, 2003.

Black's Law Dictionary, Seventh Edition.

Emil S. Tarigan, Lampiran - Laporan Keuangan, disampaikan pada Akuntansi Untuk Praktisi Hukum, LPLIH Jakarta, Mei 2002, h.1.

- Standar Akuntansi Keuangan (Prinsip-Prinsip Akuntansi), disampaikan pada Akuntansi Untuk Praktisi Hukum, LPLIH Jakarta, Mei 2002.

Gische, David M., \& Jo Ann Abramson of Ross Dixon \& Bell, LLP, http://www.findlaw.com/Corporate Fiduciary Liability Claims in the Post-Enron Era http://articles.corporate.finlaw.com/articles/file/00295/ 008474.

Kamus Besar Bahasa Indonesia Edisi Kedua, Departemen Pendidikan dan Kebudayaan, cet ketiga: 1994.

Keong, Low Chee. Introduction the Corporate Governance Debate, Corporate Governance an Asia Pacific Critique, Sweet \& Maxwell Asia a Thompson Company.

Nur, Basyiruddin. Accounting for Lawyer, disampaikan pada Pendidikan Khusus Profesi Advokat di Fakultas Hukum Universitas Indonesia 2005.

Organization of Economic Cooperation and Development (OECD), Good Corporate Governance Principles 2004.

Sensi W., Ludovicus. Tanggung Jawab Akuntan Manajemen dan Akuntan Publik atas Skandal Akuntansi (Korporasi) dilihat dari sudut pandang Akuntan Publik (Global Issues and Perspective), disampaikan pada Akuntansi untuk Praktisi Hukum, yang diselenggarakan oleh LPLIHFHUI, Mei 2003.

Tjager, I Nyoman, F. Antonius Alijoyo, Humphrey R. Djemat, dan Bambang Soembodo, Corporate Governance - Tantangan dan Kesempatan bagi Komunitas Bisnis Indonesia, Jakarta: PT Prenhallindo, tanpa tahun.

Trisnoprasetio, Prio. Divisi Pendidikan dan Latihan, DPP SPI, Makalah Membaca Laporan Keuangan. 
Tochfa, Ki Agus Umar. Direktur Keuangan PT ANTAM Tbk., Membuat Annual Report yang Efektif serta Sesuai dengan Prinsip-Prinsip Good Corporate Governance dan Studi Kasus, disampaikan dalam Seminar Good Annual Report dalam Perspektif Good Corporate Governance di Hotel Mulia, 28 Oktober 2002.

Widjaya, I.G. Rai. Hukum Perusahaan - Undang-undang dan peraturanperaturan perlaksana di bidang usaha, cet.1. Jakarta: Kesaint Blanc, 2000 . 